\title{
Relationship of Family Support and Role of Cadre With Frequency of Visit of Elderly Posyandu in Work Area Public Health Center of Karang Mekar Banjarmasin
}

\author{
Novita Dewi Iswandari ${ }^{1}$, Bagus Rahmat Santoso ${ }^{2}$,Desiana ${ }^{3}$ \\ \{novitadewiiswandari@yahoo.com ${ }^{1}$,ners_b4gs@yahoo.com ${ }^{2}$, \\ desshyana.garang@gmail.com ${ }^{3}$ \}
}

Sari Mulia University, Banjarmasin, South Kalimantan 70238, Indonesia ${ }^{1,2,3}$

\begin{abstract}
The important role in the successful implementation of the elderly posyandu is family support and cadres. Family support encourages the interest and motivation of the elderly to visit the posyandu while cadres have an important role as a driving force in carrying out the goals of the elderly posyandu. This study aimed to determine the relationship of family support and the role of cadres with the frequency of elderly visit in posyandu. This study used a cross sectional approach. A total of 47 elderly people were distributed questionnaires related to family support and cadre roles related to the frequency of elderly visits. From the two research variables there was only one related variable namely family support with the frequency of elderly posyandu visits while no association was found between the cadre's role and the frequency of elderly posyandu visits.
\end{abstract}

Keywords: Family support, visit frequency, cadre role, posyandu elderly

\section{Introduction}

An indicator of the success of development is the increasing life expectancy. The increasing life expectancy of the population, causing the number of elderly population continues to increase from year to year [1]. Law of the Republic of Indonesia Number 13 of 1998 concerning Elderly Welfare Chapter I Article 1, what is meant by Elderly is someone who has reached the age of 60 years and above. [2] slowly and maintain its normal structure and function so that it cannot withstand the infection and repair the damage suffered [3].

The increase in the number of elderly can be seen from the increase in the number of elderly people in Indonesia in 2014 amounting to 19,142,861 people and an increase in 2015 of 21.685.326 people [4]. Based on the data of the Banjarmasin City Health Profile in 2015 the number of elderly people was 36.469 elderly. consisting of 17.551 elderly men and 18.918 elderly women. There was an increase in the number of elderly in 2016 to 50.158 elderly consisting of 23.976 elderly men and 26,182 elderly women. In 2016 the number of elderly visits to health services was 38.100 elderly (76\%), more than the number of elderly visits to health services in 2015 which was 28.119 elderly (77.10\%). In 2015 the visit of the posyandu for the elderly at 
Karang Mekar Health Center in Banjarmasin ranked 19th out of 26 Puskesmas in the city of Banjarmasin with a number of visits of 339 elderly (80.14\%) out of 423 elderly and in 2016 there was a decrease in the visit of the posyandu for the elderly to the lowest order with the number of visits was 174 elderly (21\%) out of 818 elderly [5].

Elderly Posyandu is an integrated service post for elderly people in a certain area that has been agreed upon, which is driven by the community where they can get health services. [6] sports and arts and culture and other services needed by the elderly in order to improve the quality of life through improving their health and well-being. In addition they can indulge and develop their own potential [7].

The elderly Posyandu cadre is the most important mover in carrying out the objectives of the elderly Posyandu. Cadres in carrying out health services at the posyandu are important resources that are needed to achieve optimal performance. In this case, elderly posyandu cadres are also required to provide optimal services so that the performance issued is good and service users in this case the elderly can also feel comfort in the elderly Posyandu [8].

Ased on the results of the study by discussing 2 health workers at Karang Mekar Health Center in Banjarmasin it is known that the role of cadres in the elderly posyandu is quite good in carrying out the activities of the elderly posyandu and informing the elderly about the importance of visiting the elderly posyandu. Obstacles that result in an average every month the elderly who come to the elderly Posyandu can be said to be a little due to the lack of family support so the lack of interest in the elderly to visit the elderly Posyandu. The results of discussions with 8 elderly who visited the Karang Mekar Health Center in Banjarmasin found that 3 elderly people received family support by delivering and accompanying the elderly to the elderly posyandu, 3 elderly did not get family support because family members were busy working so that no one reminded and escorted the elderly posyandu, while 2 elderly visited the elderly Posyandu only for treatment when they were sick. It can be seen from the book of elderly visits over the past year that 8 elderly people who have been asked show that 3 elderly people who received family support from posyandu visits had more than 8 visits, while 5 elderly did not have family support. Posyandu visits were less than 8 visits.

\section{Methods}

This research is a quantitative research using analytic survey method with Cross Sectional approach. The population in this study were all elderly in the working area of Karang Mekar Health Center, Banjarmasin. Population data was taken in the last 1 month, August 2017 with the number of elderly visiting the Posyandu for the elderly with a total sampling technique of 47 elderly. Data analysis techniques with Chi Square test. 


\section{Results}

\subsection{Univariate Analysis}

a. Family support

Table 1. Frequency distribution of family support

\begin{tabular}{ccc}
\hline Family Support & $\mathrm{f}$ & $\%$ \\
\hline Positive & 20 & 42.6 \\
Negative & 27 & 57.4 \\
\hline Amount & 47 & 100 \\
\hline
\end{tabular}

Based on table 1, the highest result of family support is negative by 27 people $(57.4 \%)$ The results of this study are in accordance with Azrul's theory (2008) that family support that can be given to the elderly can be given attention, appreciation or help the parents by accepting their conditions, Family support is obtained from individuals and groups. Family support is very influential in motivating the elderly to actively visit posyandu for the elderly [9].

This study is in line with Asti Wijayanti's research (2017) that family support for the elderly in Ngempon Village, Bergas District, Semarang Regency, mostly in the unfavorable category, which is 41 elderly people (55.4\%) and good 33 elderly people (44.6\%) [10].

b. The role of cadres

Table 2. Frequency distribution of cadre roles

\begin{tabular}{ccc}
\hline Cadre roles & $\mathrm{f}$ & $\%$ \\
\hline Good & 28 & 59.6 \\
Less & 19 & 40.4 \\
\hline Amount & 47 & 100
\end{tabular}

Based on table 2, the highest cadre role was 28 people (59.6\%). This research is in accordance with the theory proposed by Margiyati (2010) that the role and task of elderly cadres is to mobilize the community, assist health workers, manage cadre monthly meetings and manage posyandu monthly reports that are already running well and will affect the elderly towards visits to posyandu because of their pleasant service, friendly, and provide information and health counseling that is clear and easy to understand for the elderly from health workers, so that the elderly are aware to come to Posyandu [11].

This is in line with research conducted by Monica Salakay (2015) that the role of cadres in the use of elderly Posyandu shows that the role of cadres is good as many as 41 respondents and the role of cadres is not good as many as 27 respondents [12]. 
c. Frequency of elderly posyandu visits

Table 3. Frequency distribution of elderly Posyandu visits

\begin{tabular}{ccc}
\hline $\begin{array}{c}\text { Posyandu } \\
\text { visits }\end{array}$ & $\mathrm{f}$ & $\%$ \\
\hline Active & 17 & 36.2 \\
Not Active & 30 & 63.8 \\
\hline Amount & 47 & 100 \\
\hline
\end{tabular}

Based on table 3, the highest number of elderly posyandu visits was inactive for 30 people $(63.8 \%)$. This research is in accordance with the theory put forward by Sulistyorini, (2010) that the frequency of inactive posyandu visits is posyandu visits $<8$ times in the last 1 year [6]. Posyandu activities for the elderly can be done at least once a month. This theory is also supported by the theory of Fallen \& Dwi (2010) that inactivity to Posyandu makes elderly health difficult to be served. This is because one of the centers for providing health services to the elderly is the elderly posyandu. As it is known that the Posyandu for the elderly aims to increase the reach of the health services of the elderly in the community, so that health services are formed in accordance with the needs of the elderly [13].

This study is supported by the research of Imam Zainuri (2014) that the activeness of the posyandu is active as many as 35 elderly (41.2\%) and inactive as many as 50 elderly (58.8\%). Inability to Posyandu assumes that posyandu does not really have the importance to be followed, other than that the elderly assume that if there is no provision of food or material matters, there is no need to actively visit the Posyandu, maintaining health can be done at home or when to other health services [14 ]

\subsection{Bivariate Analysis}

a. Relationship of family support with the frequency of elderly posyandu visits

Table 4. Cross tabulation of the relationship of family support with the frequency of elderly posyandu visits

\begin{tabular}{ccccccc}
\hline \multirow{2}{*}{$\begin{array}{c}\text { Family } \\
\text { Support }\end{array}$} & \multicolumn{4}{c}{$\begin{array}{c}\text { Frequency of elderly } \\
\text { posyandu visits }\end{array}$} & \multirow{2}{*}{ Total } \\
\cline { 2 - 5 } & \multicolumn{2}{c}{ Active } & \multicolumn{2}{c}{ Not Active } & & \\
\cline { 2 - 6 } & $\mathrm{f}$ & $\%$ & $\mathrm{f}$ & $\%$ & $\mathrm{~N}$ & $\%$ \\
\hline Positive & 13 & 27.7 & 7 & 14.9 & 20 & 42.6 \\
\hline Negative & 4 & 8.5 & 23 & 48.9 & 27 & 57.4 \\
\hline Amount & 17 & 36.2 & 30 & 63.8 & 47 & 100 \\
\hline \multicolumn{9}{c}{$P$ Value $=0.000$} \\
\hline
\end{tabular}

Based on table 4 , it shows that the highest family support is negative by not actively visiting the elderly keposyandu by 23 people $(48.9 \%)$. Bivariate analysis using Chi Square test obtained $\mathrm{p}$ value $=0,000$ with $\mathrm{a}=0.05$. Then the value of $\mathrm{p}(0,000)<\mathrm{a}(0.05)$, meaning $(\mathrm{Ho})$ rejected $(\mathrm{Ha})$ is accepted then there is a relationship of family support with the frequency of elderly Posyandu visits in the Karang Mekar Community Health Center Banjarmasin. 
This research is in line with Sunaryo's (2014) theory which states that factors affecting elderly visits include family support. Family function is a set of behaviors that are expected in accordance with the social position given by the family to its members. Based on this understanding, the family has several functions that can be carried out namely biological, psychological (giving attention among family members), social functions, economic functions and education [15].

The results of this study are in line with research conducted by Herlina (2015) which states that there is a relationship between family support and elderly visits to posyandu elderly. Based on the calculated $\mathrm{r}$ value obtained data of $\mathrm{r}=0.494$ this shows the correlation value is quite strong [16].

b. The relationship between the role of cadres and the frequency of elderly Posyandu visits

Table 5. Cross tabulation of the relationship between cadre roles and the frequency of elderly posyandu visits

\begin{tabular}{|c|c|c|c|c|c|c|}
\hline \multirow{3}{*}{$\begin{array}{l}\text { The Role } \\
\text { of Cadre }\end{array}$} & \multicolumn{4}{|c|}{$\begin{array}{l}\text { Frequency of elderly } \\
\text { Posyandu visit }\end{array}$} & \multirow{2}{*}{\multicolumn{2}{|c|}{ Total }} \\
\hline & \multicolumn{2}{|c|}{ Active } & \multicolumn{2}{|c|}{ Not Active } & & \\
\hline & $\mathrm{f}$ & $\%$ & $\mathrm{f}$ & $\%$ & $\mathrm{~N}$ & $\%$ \\
\hline Good & 11 & 23.4 & 17 & 36.2 & 28 & 59.6 \\
\hline Less & 6 & 12.8 & 13 & 27.7 & 19 & 40.4 \\
\hline Amount & 17 & 36.2 & 30 & 63.8 & 47 & 100 \\
\hline
\end{tabular}

Based on table 5, it shows that the highest cadre role is good by not actively visiting the elderly keposyandu by 17 people $(36.2 \%)$. Bivariate analysis using Chi Square test obtained $\mathrm{p}$ value $=0.589$ with $\mathrm{a}=0.05$. Then the $\mathrm{p}$ value $(0.589<\mathrm{a}(0.05)$, meaning that (Ho) is accepted (Ha) is rejected then there is no relationship between the role of cadres and the frequency of elderly posyandu visits in the Karang Mekar Community Health Center in Banjarmasin.

This study is in line with Setyatama's theory (2012) the role of cadres is needed in the use of elderly Posyandus such as weighing, measuring blood pressure, health education, filling in KMS, and playing an active role in inviting elderly people to come to elderly Posyandu [17].

The results of this study are not in line with research conducted by Ughniyatu (2016) that the role of cadres can influence the activeness of elderly posyandu visits. The better the role of cadres in carrying out Posyandu, the higher the activity of visits to Posyandu elderly [18]. 


\section{Conclusions}

Based on the results of research conducted at the Karang Mekar Health Center in Banjarmasin, it was found that there was a relationship of family support with the fermentation of elderly poyandu visits $(\mathrm{p}=0,000)$ and there was no relationship between the role of cadres and the frequency of elderly posyandu visits $(\mathrm{p}=0.589)$.

\section{Acknowledgements}

Thank you to the Chancellor of Sari Mulia University for providing support in conducting research and the Head of Karang Mekar Health Center who has facilitated the research site.

\section{References}

[1] Departemen Kesehatan Republik Indonesia: Laporan Nasional Riset Kesehatan Dasar. Pusat Penelitian Pengembangan Kesehatan, jakarta (2013)

[2] Indriana, Yeniar: Gerentologi dan Progeria. Pustaka Belajar, Yogyakarta (2012)

[3] Nugroho, Wahyudi: Keperawatan Gerontik dan Geriatrik Edisi 3. EGC, Jakarta (2008)

[4] Kementerian Kesehatan Republik Indonesia: Profil Kesehatan Indonesia 2015. Dinas Kesehatan Indonesia, Jakarta (2015)

[5] Dinas Kesehatan Kota Banjarmasin: Profil Kesehatan 2015 Kalimantan Selatan.Dinas Kota Banjarmasin, Banjarmasin (2015)

[6] Sulistyorini, Cahyo Ismawati dkk: POSYANDU (Pos Pelayanan Terpadu) DAN DESA SIAGA. Nuha Medika, Yogyakarta (2010)

[7] Soeweno, Inten: Pedoman Pelaksaan Posyandu Lanjut Usia. Komnas Lansia, Jakarta (2010)

[8] Yulifah, Rita dan Yuswanto, Tri Johan Agus : Asuhan Kebidanan Komunitas Edisi 2.Salemba Medika, Jakarta (2014)

[9] Azrul: Pengantar administrasi kesehatan edisi ketiga. Binarupa Aksara, Jakarta (2008)

[10] Asti Wijayanti: Hubungan Dukungan Keluarga terhadap Perilaku Lansia untuk Berkunjung Ke Posyandu Lansia di Desa Ngempon Kecamatan Bergas Kabupaten Semarang Tahun 2017. Progam Studi D III Kebidanan Fakultas Ilmu Kesehatan Universitas Ngudi Waluyo (2017)

[11] Margiyati : Pengaruh Senam Lansia Terhadap Penurunan Tekanan Darah pada Lansia Penderita Hipertensi di Posyandu Lansia Ngudi Waras, Dusun kemloko, Desa Bergas Kidul. Skripsi. Program Sarjana UNDIP. Semarang (2010)

[12] Monica Salakay: Hubungan Dukungan Keluarga, Sikap dan Peran Kader Kesehatan Dengan Pemanfaatan Posyandu Lansia di Kelurahaan Taas Kecamatan Tikala Kota Manado. (Skripsi). Fakultas Kesehatan Masyarakat Universitas Sam Ratulangi Manado(2015)

[13] Fallen \& Dwi : Catatan kuliah keperawatan komunitas. Yogyakarta: Nuha Medika, Yogyakarta (2010) 
[14] Imam Zainuri : Hubungan Harga Diri Dengan Kunjungan Lansia ke Posyandu Lansia di Desa Kejapanan Kecamatan Gempol Kabupaten Pasuruan. STIKES Bina Sehat PPNI Mojokerto (2014)

[15] Sunaryo: Psikologi Untuk Keperawatan. EGC, Jakarta (2014)

[16] Herlina : Hubungan Dukungan Keluarga dengan Kunjungan Lansia ke Posyandu Lansia.Jurnal Keperawatan \& Kebidanan - Stikes Dian Husada, Mojokerto (2015)

[17] Setyatama : Hubungan Pengetahuan dan Motivasi Kader dengan Peran Kader Posyandu Lansia di Desa Kangkung Kecamatan Mranggen Kabupaten Demak. [Karya tulis ilmiah]. Semarang: Akademi Kebidanan Karsa Mulia Semarang (2012)

[18] Ughniyatul : Hubungan Peran Kader Dengan Keaktifan Kunjungan Posyandu Lansia di Wilayah Kerja Puskesmas Godean II. D4 Bidan Pendidik Universitas Gadjah Madya ,Yogyakarta (2016) 